\title{
Dietary nutrient profiles of wild wolves: insights for optimal dog nutrition? ${ }^{\text {is }}$
}

\author{
Guido Bosch $^{1 *}$, Esther A. Hagen-Plantinga ${ }^{2}$ and Wouter H. Hendriks ${ }^{1,2}$ \\ ${ }^{1}$ Animal Nutrition Group, Wageningen University, PO Box 338, 6700 AH Wageningen, The Netherlands \\ ${ }^{2}$ Faculty of Veterinary Medicine, Utrecht University, PO Box 80.151, 3508 TD Utrecht, The Netherlands
}

(Submitted 22 November 2013 - Final revision received 4 April 2014 - Accepted 6 June 2014 - First published online 21 November 2014)

\begin{abstract}
Domestic dogs diverged from grey wolves between 13000 and 17000 years ago when food waste from human settlements provided a new niche. Compared to the carnivorous cat, modern-day dogs differ in several digestive and metabolic traits that appear to be more associated with omnivorous such as man, pigs and rats. This has led to the classification of dogs as omnivores, but the origin of these 'omnivorous' traits has, hitherto, been left unexplained. We discuss the foraging ecology of wild wolves and calculate the nutrient profiles of fifty diets reported in the literature. Data on the feeding ecology of wolves indicate that wolves are true carnivores consuming a negligible amount of vegetal matter. Wolves can experience prolonged times of famine during low prey availability while, after a successful hunt, the intake of foods and nutrients can be excessive. As a result of a 'feast and famine' lifestyle, wolves need to cope with a highly variable nutrient intake requiring an adaptable metabolism, which is still functional in our modern-day dogs. The nutritive characteristics of commercial foods differ in several aspects from the dog's closest free-living ancestor in terms of dietary nutrient profile and this may pose physiological and metabolic challenges. The present study provides new insights into dog nutrition and contributes to the ongoing optimisation of foods for pet dogs.
\end{abstract}

Key words: Dogs: Cats: Dietary recommendations: Feeding ecology

The domestic dogs (Canis familiaris) and man share a long history of co-existence that intensified over time to 'man's best friend' and a 'family member' we keep in many of our homes today. When man lived as nomadic hunter-gatherers, encampments likely attracted carnivorous grey wolves (Canis lupus), the dog's direct ancestors, to scavenge kills or opportunistically take wounded animals that escaped the hunt ${ }^{(1,2)}$. After the transition from the Paleolithic to Neolithic Era between 13000 and 17000 years ago, when man became sedentary and started agriculture in the Fertile Crescent of the Near or Middle East, a new food niche emerged consisting of human-derived vegetal and animal food waste items ${ }^{(3)}$. Wolves opportunistically took advantage of this niche, gradually becoming accustomed to human contact and, over generations, with the multiple domestication and/or interbreeding events with their wild counterparts, the domesticated dog evolved ${ }^{(2,4)}$. Breeding efforts during the last 3000-4000 years and, in particular, over the past two centuries have resulted in the remarkable morphological and behavioural diversity of dogs we know today ${ }^{(2,3)}$. The majority of the morphological diversity among dog breeds has a simple genetic basis dominated by less than four quantitative trait loci ${ }^{(5)}$. Although most modern-day dogs no longer look like wolves, they can still interbreed and produce fertile offspring ${ }^{(6)}$ making dogs a subspecies of wolves. Considering the relatively short time span in which domestication occurred and the close genetic relationship, the dog's genome would still predominantly be the product of the environmental selective pressures imposed upon its ancestor, the wolf. Recent evidence shows that three genes ( $A M Y 2 B, M G A M$ and SGLT1) involved in starch digestion and glucose uptake were the target of selection during domestication ${ }^{(7)}$. The $A M Y 2 B$ copy number expansion is, however, not fixed across all dog breeds. The Saluki, an ancient breed originating from the Fertile Crescent, showed twenty-nine copies. Ancient breeds such as the Dingo and Siberian Husky show no or limited the expansion (three to four copies), which suggests that these breeds arose alongside hunter-gatherers rather than agriculturists $^{(8)}$. These recent studies also show that other metabolic traits observed in dogs, like capacity to synthesise sufficient

Abbreviations: BW, body weight; ME, metabolisable energy; NFE, N-free extract.

*Corresponding author: G. Bosch, email guido.bosch@wur.nl

This article was published as part of the WALTHAM International Nutritional Sciences Symposium Proceedings 2013.

This paper was published as part of a supplement to British Journal of Nutrition, publication of which was supported by an unrestricted educational grant from Mars Incorporated. The papers included in this supplement were invited by the Guest Editor and have undergone the standard journal formal review process. They may be cited. 
amounts of essential nutrients such as niacin, taurine and arginine, were unaffected by domestication. Dogs typically differ in these traits from carnivorous cats (Felis catus) and, in this respect, resemble omnivorous man, pigs and rats. Similar to the 'metabolic idiosyncrasies' of cats, their carnivorous nature is also reflected in recent studies focusing on the macronutrient selection by adult cats ${ }^{(9,10)}$. Cats choose a protein-fat-carbohydrate profile consisting of $52: 36: 12 \%$ by energy, which closely matches with the macronutrient profile of free-roaming cats being $52: 46: 2 \%$ by energy $^{(11)}$.

The scientific confirmation of the absence of identical or similar specialised metabolic pathways in dogs has led many scientists to question the once-firm carnivorous classification of our domesticated dogs. This 'omnivorous dog dogma' has developed over the past 40 years and has found its way into authoritative scientific reference books ${ }^{(12,13)}$, nutritional concepts in pet nutrition and as a general view. The apparent contradiction between the dogs' lack of carnivorous traits similar to cats and their ancestral carnivorous ecology has, hitherto, been left unexplained. Here, we present an explanation for the origin of the lack of similar 'idiosyncratic' metabolic adaptations of dogs compared to cats by taking into account the foraging ecology and nutrient intake of modern wolves. A literature review of studies reporting data on diet compositions based on stomach contents and scat analyses was used to calculate the nutrient intake of modern wolves.

\section{Dietary and nutrient profiles consumed by wolves}

An overview of twenty-six studies reporting fifty diet compositions of wolves in their natural habitat and based on 31276 wolf scat and stomach analyses is shown in Table 1 . The various diet compositions reported in the literature show that wolves in their natural habitat consume a diet predominantly composed of ungulates but supplemented with smaller mammals such as beavers, hares and rodents (Table 2). In Europe, the major dietary items consumed were wild boar, moose, roe deer and red deer. Beavers (Castor fiber) were overall a less common prey animal but contributed $12.6 \%$ of total percentage of weight in one study conducted in the summer in Latvia ${ }^{(14)}$. Various other non-ungulate species were consumed by wolves in Europe but contributed overall little $(<7.8 \%)$ to the total biomass consumed. Other types of animals consumed were birds, reptiles, insects and fish. In North-America, wolves preyed predominantly on moose, white-tailed deer and beaver (Castor canadensis). Diets also contained various medium-size and small prey animals, with the snowshoe hare (Lepus americanus) being the most common but their contribution to the total amount of biomass consumed was low $(\leq 2.5 \%)$. Darimont et al. ${ }^{(15)}$ found that considerable amounts of mustelidae were consumed by wolves in Western Canada. Other types of animals consumed were birds, insects, intertidal organisms and fish.

Plant material was identified in scats in several studies, but the contribution of plant material to the total biomass consumed was not always calculated. For example, Fritts \& $\mathrm{Mech}^{(16)}$ did not include grass in the food analyses calculation as it was not considered a food item, although it could have been ingested intentionally by wolves. For example Jedrzejewski et al. ${ }^{(17)}$ detected grasses and sedges in $32.6 \%$ of all faecal samples. Most often, the grass was present in well-ordered bundles, and in some cases ( $n$ 5), it occupied more than $50 \%$ and up to $100 \%$ of the scat by relative volume $^{(17)}$. It has been hypothesised that consumed grass may act as a scouring agent against intestinal parasites such as roundworms and tapeworms (see Peterson ${ }^{(18)}$ ). Those studies that did include plant material in their food analyses reported values between $0 \cdot 1$ and $3 \%$ of the total percentage of weight. Identifiable fruit items found in scats included blueberries (Vaccinium spp.) ${ }^{(16,19-21)}$, strawberries (Fragaria spp.) ${ }^{(16)}$ and raspberries (Rubus spp. $)^{(19,22)}$, other berries (Juniperus communis and Vitis vinifera) ${ }^{(23)}$, nuts (Juglans regia, Corylus avellana, Fagus sylvatica and Castanea sativa) ${ }^{(23)}$ and other fruits (Rosa spp., Malus spp., Pyrus spp., Prunus spp., Rubus spp. and Sorbus spp.) ${ }^{(22,23)}$. Corn (Zea mays) was also detected in scats by Wagner et al. ${ }^{(22)}$ The fruit items contain some energy in the form of carbohydrates (see online supplementary Table S4) but are, compared to the other dietary items, considerably lower in most other nutrients making their contribution to the overall nutrient intake of wolves negligible. Furthermore, it has been suggested that fruit items are primarily consumed by pups $^{(16,21)}$. The consumption of fruit items may underlay the tasting capacity of dogs that cats lack. Dogs have Type D units of taste receptors that respond to a small number of 'fruity-sweet' compounds ${ }^{(24)}$. Consumption of vegetable matter is also observed in other carnivores such as polar bears (Ursus maritimus) ${ }^{(25,26)}$ and crocodilians ${ }^{(27)}$. Contrary to popular belief, wolves do not consume the (partly fermented) vegetable matter in the rumen of ungulates ${ }^{(18,19,28-33)}$. During removal, however, the rumen can be punctured and its contents spilled ${ }^{(29)}$ of which some can be consumed along with other body tissues ${ }^{(30)}$. Furthermore, the rumen lining and the intestinal wall can be consumed ${ }^{(29,30)}$. Based on these studies reporting data on the foraging ecology, wolves can be considered true carnivores in their nature with vegetal matter being a minor to negligible component of their overall diet.

For the calculation of the nutrient profiles, the data on the dietary items were combined with data on the nutrient composition of each dietary item (see online supplementary material). Similar approaches as used here have been applied for the evaluation of nutrient profiles of the diet of freeranging cats ${ }^{(11)}$, badgers ${ }^{(34)}$, kiwi birds (Apteryx mantelli) ${ }^{(35)}$, and that of the hunter-gatherers or Palaeolithic diet of human subjects ${ }^{(36-40)}$. The mean dietary DM content was $38.6 \%$ with crude protein contributing the largest part to the DM content (mean $67.2 \%$ of DM) followed by EE $(24.9 \%$ of DM) and then ash (6.4\% of DM) (Fig. 1). The dietary content of N-free extract (NFE) was the lowest and contributed $1.4 \%$ to DM. The mean energy content was $2085 \mathrm{~kJ} / 100 \mathrm{~g}$ DM and ranged from 2004 to $2244 \mathrm{~kJ} / 100 \mathrm{~g}$ DM. The mean Ca content was $1.30 \mathrm{~g} / 100 \mathrm{~g}$ DM and varied between 0.83 and $2.04 \mathrm{~g} / 100 \mathrm{~g}$ DM. The ratio between $\mathrm{Ca}$ and $\mathrm{P}$ varied between 0.83 and 1.30 and was on average 1.05 . Mean values for $\mathrm{Na}$ and $\mathrm{K}$ contents were 0.28 and $0.99 \mathrm{~g} / 100 \mathrm{~g} \mathrm{DM}$, respectively, and showed little variation. Mean dietary contents of 
NS British Journal of Nutrition

Table 1. Overview of the considered studies presenting diet compositions expressed as percentage of weight for inclusion in the calculations to determine the nutrient composition of wild wolf diets

Study

\begin{tabular}{|c|c|c|c|c|c|c|}
\hline No. & Reference & Details & Period & Material & Samples $(n)$ & Reason for exclusion \\
\hline \multirow[t]{2}{*}{1} & \multirow[t]{2}{*}{ Andersone \& Ozolinš ${ }^{(14)}$} & Summer, Latvia & April-September & Stomachs, scats & 246 & \\
\hline & & Winter, Latvia & October-March & Stomachs, scats & 163 & \\
\hline 2 & Ansorge et al. ${ }^{(81)}$ & Germany & Year & Scats & 192 & \\
\hline 3 & Ballard et al. ${ }^{(82)}$ & Alaska, USA & May-June & Scats & 5559 & \\
\hline 4 & $\operatorname{Barja}^{(83)}$ & Spain & Year & Scats & 593 & $\mathrm{HLF}>5 \%$ \\
\hline \multirow[t]{3}{*}{5} & \multirow[t]{3}{*}{ Capitani et al. ${ }^{(84)}$} & A. Susa Valley, Italy & Year & Scats & 194 & HLF $>5 \%$ \\
\hline & & B. Pratomagno, Italy & Year & Scats & 355 & \\
\hline & & C. Cecina Valley, Italy & Year & Scats & 118 & $\mathrm{HLF}>5 \%$ \\
\hline 6 & Ciucci et al. ${ }^{(85)}$ & Italy & Year & Scats & 217 & HLF $>5 \%$ \\
\hline 7 & Ciucci et al. ${ }^{(86)}$ & Italy & Year & Scats & 200 & HLF $>5 \%$ \\
\hline \multirow[t]{3}{*}{8} & \multirow[t]{3}{*}{ Chavez \& Gese ${ }^{(87)}$} & A. Minnesota, USA, 1997 & Summer-Autumn & Scats & 199 & HLF $>5 \%$ \\
\hline & & B. Minnesota, USA, 1998 & Summer-Autumn & Scats & 101 & $\mathrm{HLF}>5 \%$ \\
\hline & & C. Minnesota, USA, 1999 & Summer-Autumn & Scats & 232 & HLF $>5 \%$ \\
\hline \multirow[t]{5}{*}{9} & \multirow[t]{5}{*}{ Cuesta et al. ${ }^{(88)}$} & A. Area I, Spain & Year & Stomachs & 92 & $n<94, \mathrm{HLF}>5 \%$ \\
\hline & & B. Area II, Spain & Year & Stomachs & 44 & $n<94, \mathrm{HLF}>5 \%$ \\
\hline & & C. Area III, Spain & Year & Stomachs & 65 & $n<94$, HLF $>5 \%$ \\
\hline & & D. Area IV, Spain & Year & Stomachs & 12 & $n<94, \mathrm{HLF}>5 \%$ \\
\hline & & E. Area V, Spain & Year & Stomachs & 13 & $n<94, \mathrm{HLF}>5 \%$ \\
\hline 10 & Darimont et al..$^{(15)}$ & British Columbia, Canada & June-August & Scats & 595 & \\
\hline \multirow[t]{6}{*}{11} & \multirow{6}{*}{ Forbes \& Theberge ${ }^{(89)}$} & A. Area A, Ontario, Canada & Summer & Scats & $371^{*}$ & \\
\hline & & B. Area B, Ontario, Canada & Summer & Scats & $186^{*}$ & \\
\hline & & C. Area C, Ontario, Canada & Summer & Scats & $823^{*}$ & \\
\hline & & D. Area A, Ontario, Canada & Winter & Scats & $208^{*}$ & \\
\hline & & E. Area B, Ontario, Canada & Winter & Scats & $461^{*}$ & \\
\hline & & F. Area C, Ontario, Canada & Winter & Scats & $767^{\star}$ & \\
\hline \multirow[t]{2}{*}{12} & \multirow[t]{2}{*}{ Fritts \& $\operatorname{Mech}^{(16)}$} & A. Minnesota, USA & April-September & Scats & 670 & $\mathrm{HLF}>5 \%$ \\
\hline & & B. Minnesota, USA & October-March & Scats & 174 & \\
\hline 13 & Fuller \& Keith ${ }^{(90)}$ & Alberta, Canada & May-September & Scats & 1524 & \\
\hline \multirow[t]{2}{*}{14} & \multirow[t]{2}{*}{ Fuller ${ }^{(19)}$} & Summer, Minnesota, USA & April-October & Scats & NSt & \\
\hline & & Winter, Minnesota, USA & November-March & Scats & NSt & \\
\hline \multirow[t]{2}{*}{15} & \multirow{2}{*}{ Gade-Jørgensen \& Stagegaard ${ }^{(20)}$} & Summer, Finland & May-September & Scats & 156 & $\mathrm{HLF}>5 \%$ \\
\hline & & Winter, Finland & October-April & Scats & 104 & \\
\hline \multirow[t]{2}{*}{16} & \multirow[t]{2}{*}{ Jedrzejewski et al. ${ }^{(91)}$} & Summer, Poland & May-September & Scats & 45 & $n<94$ \\
\hline & & Winter, Poland & October-April & Scats & 99 & \\
\hline \multirow[t]{2}{*}{17} & \multirow{2}{*}{ Jedrzejewski et al. ${ }^{(17)}$} & Summer, Poland & May-September & Scats & 67 & $n<94$ \\
\hline & & Winter, Poland & October-April & Scats & 344 & \\
\hline 18 & Jedrzejewski et al. ${ }^{(92)}$ & Poland & Year & Scats & 328 & \\
\hline 19 & Jethva \& Jhala ${ }^{(93)}$ & India & Year & Scats & 1246 & HLF $>5 \%$ \\
\hline 20 & Kojola et al. ${ }^{(94)}$ & A. Area I, Finland & Year & Scats & 167 & \\
\hline & & B. Area II, Finland & Year & Scats & 117 & \\
\hline & & C. Area III, Finland & Year & Scats & 159 & \\
\hline 21 & Lanszki et al. ${ }^{(95)}$ & Hungary & Year & Scats & 81 & $n<94$ \\
\hline 22 & Liu \& Jiang ${ }^{(96)}$ & Qinghai, China & Year & Scats & 119 & HLF $>5 \%$ \\
\hline 23 & Mattioli et al. ${ }^{(97)}$ & Italy & Year & Scats & 240 & HLF $>5 \%$ \\
\hline 24 & Mattioli et al. ${ }^{(98)}$ & A. Area ISA, Italy & Year & Scats & 1862 & \\
\hline & & B. Area SAF, Italy & Year & Scats & $>113$ & \\
\hline & & C. Area VS, Italy & Year & Scats & $>97$ & $\mathrm{HLF}>5 \%$ \\
\hline & & D. Area PM, Italy & Year & Scats & $>203$ & \\
\hline & & E. Area VT, Italy & Year & Scats & $>174$ & $\mathrm{HLF}>5 \%$ \\
\hline 25 & Meriggi et al. ${ }^{(23)}$ & A. Area A, Italy & Year & Scats & 292 & $\mathrm{HLF}>5 \%$ \\
\hline
\end{tabular}


Table 1. Continued

\begin{tabular}{|c|c|c|c|c|c|c|}
\hline \multicolumn{7}{|c|}{ Study } \\
\hline No. & Reference & Details & Period & Material & Samples $(n)$ & Reason for exclusion \\
\hline & & B. Area B, Italy & Year & Scats & 71 & $n<94, \mathrm{HLF}>5 \%$ \\
\hline & & C. Area C, Italy & Year & Scats & 156 & \\
\hline \multirow[t]{2}{*}{26} & Messier \& Crête ${ }^{(99)}$ & A. Area H, Québec, Canada & May-November & Scats & 220 & \\
\hline & & B. Area M, Québec, Canada & May-November & Scats & 408 & \\
\hline 27 & Milanesi et al. ${ }^{(100)}$ & Italy & Year & Scats & 103 & $\mathrm{HLF}>5 \%$ \\
\hline \multirow[t]{5}{*}{28} & Nowak et al. ${ }^{(101)}$ & A. Bydgoscz Forest, Poland & Year & Scats & 81 & $n<94$ \\
\hline & & B. Wałcz Forest, Poland & Year & Scats & 112 & \\
\hline & & C. Rzepin Forest, Poland & Year & Scats & 126 & \\
\hline & & D. Lower Silesia Forest, Poland & Year & Scats & 124 & \\
\hline & & E. Other areas, Poland & Year & Scats & 31 & $n<94$ \\
\hline 29 & Olsson et al. ${ }^{(102)}$ & Sweden-Norway & Year & Scats & 684 & \\
\hline 30 & Peterson et al. ${ }^{(103)}$ & Alaska, USA & May-October & Scats & 592 & \\
\hline 31 & Peterson \& Page ${ }^{(104)}$ & Michigan, USA & May-August & Scats & 2648 & \\
\hline 32 & Pezzo et al. ${ }^{(105)}$ & Italy & Year & Stomachs & 38 & $n<94$ \\
\hline \multirow[t]{2}{*}{33} & Potvin et al. ${ }^{(31)}$ & Summer, Québec, Canada & May-September & Scats & 737 & \\
\hline & & Winter, Québec, Canada & December-April & Scats & 429 & \\
\hline 34 & Reed et al. ${ }^{(106)}$ & Arizona and New Mexico, USA & Year & Scats & 251 & HLF $>5 \%$ \\
\hline 35 & Reig \& Jedrzejewski ${ }^{(107)}$ & Poland & December-May & Scats & 15 & $n<94$ \\
\hline \multirow[t]{3}{*}{36} & Sidorovich et al. ${ }^{(108)}$ & A. Belarus, 1990-1992 & Year & Scats & 447 & \\
\hline & & B. Belarus, $1994-1996$ & Year & Scats & 363 & $\mathrm{HLF}>5 \%$ \\
\hline & & C. Belarus, $1999-2000$ & Year & Scats & 375 & $\mathrm{HLF}>5 \%$ \\
\hline 37 & Śmietana \& Klimek ${ }^{(109)}$ & Poland & Year & Scats & 221 & HLF $>5 \%$ \\
\hline 38 & Thurber \& Peterson ${ }^{(110)}$ & Michigan, USA & June-August & Scats & 3637 & \\
\hline \multirow[t]{4}{*}{39} & Tremblay et al. ${ }^{(21)}$ & A. Malaie pack, Québec, Canada, 1996 & May-October & Scats & 505 & \\
\hline & & B. Grands-Jardin pack, Québec, Canada, 1996 & May-October & Scats & 118 & \\
\hline & & C. Malaie pack, Québec, Canada, 1997 & May-October & Scats & 866 & \\
\hline & & D. Grands-Jardin pack, Québec, Canada, 1997 & May-October & Scats & 132 & \\
\hline 40 & $\operatorname{Vos}^{(111)}$ & Portugal & April-October & Scats & 87 & $n<94$ \\
\hline \multirow[t]{8}{*}{41} & Wagner et al. ${ }^{(22)}$ & A. Germany, $2001 / 2002$ & Year & Scats & $100^{*}$ & \\
\hline & & B. Germany, 2002/2003 & Year & Scats & $61^{*}$ & $n<94$ \\
\hline & & C. Germany, 2003/2004 & Year & Scats & $202^{*}$ & \\
\hline & & D. Germany, 2004/2005 & Year & Scats & $322^{*}$ & \\
\hline & & E. Germany, 2005/2006 & Year & Scats & $239^{*}$ & \\
\hline & & F. Germany, 2006/2007 & Year & Scats & $337^{*}$ & \\
\hline & & G. Germany, 2007/2008 & Year & Scats & $232^{*}$ & \\
\hline & & H. Germany, 2008/2009 & Year & Scats & $397^{\star}$ & \\
\hline
\end{tabular}

HLF, human-linked foods; $\mathrm{A}-\mathrm{H}$, study details with regard to area and/or year.

Number of scats is not specified in the original manuscript; number of scats after personal communication with authors (i.e. G Forbes and $C$ Wagner).

† Number of scats is not specified in the original manuscript. Considering the large number of total scats ( $n$ 2386), it was assumed to be larger than ninety-four for both seasons. 
Table 2. Data of dietary profiles of wild wolves found in the literature (\% of weight)

\begin{tabular}{|c|c|c|c|c|c|c|c|c|c|c|c|c|c|c|c|c|c|}
\hline \multirow[t]{3}{*}{ Dietary item... } & \multicolumn{17}{|c|}{ Study no. } \\
\hline & \multicolumn{2}{|c|}{1} & \multirow[t]{2}{*}{2} & \multirow[t]{2}{*}{3} & \multirow{2}{*}{$\begin{array}{l}5 \\
\text { B }\end{array}$} & \multirow[t]{2}{*}{10} & \multicolumn{6}{|c|}{11} & \multirow{2}{*}{$\begin{array}{l}12 \\
\text { B }\end{array}$} & \multirow[t]{2}{*}{13} & \multicolumn{2}{|c|}{14} & \multirow{2}{*}{$\begin{array}{l}15 \\
W\end{array}$} \\
\hline & S & W & & & & & A & B & C & $\mathrm{D}$ & E & $\mathrm{F}$ & & & $\mathrm{S}$ & W & \\
\hline \multicolumn{18}{|l|}{ Mammals } \\
\hline \multicolumn{18}{|l|}{ Ungulates } \\
\hline Black-tailed deer & - & - & - & - & - & $64 \cdot 6$ & - & - & - & - & - & - & - & - & - & - & - \\
\hline Caribou & - & - & - & $10 \cdot 4$ & - & - & - & - & - & - & - & - & - & - & - & - & - \\
\hline European bison & - & - & - & - & - & - & - & - & - & - & - & - & - & - & - & - & - \\
\hline Fallow deer & - & - & - & - & $+^{*}$ & - & - & - & - & - & - & - & - & - & - & - & - \\
\hline Livestock & $2 \cdot 3$ & 4.4 & - & - & 0.3 & - & - & - & - & - & - & - & $2 \cdot 8$ & - & - & - & + \\
\hline Moose & $+\dagger$ & $+\ddagger$ & - & $81 \cdot 1$ & 0 & 0 & $82 \cdot 1$ & $57 \cdot 6$ & 64 & $87 \cdot 3$ & $64 \cdot 6$ & $71 \cdot 7$ & $20 \cdot 7$ & $89 \cdot 3$ & - & - & 96.0 \\
\hline Mouflon & - & - & $5 \cdot 0$ & - & $+\S$ & - & - & - & - & - & - & - & - & - & - & - & - \\
\hline Mountain goats & - & - & - & - & $+\S$ & $9 \cdot 1$ & - & - & - & - & - & - & - & - & - & - & - \\
\hline Red deer & $+\dagger$ & $+\ddagger$ & $56 \cdot 7$ & - & $+^{*}$ & - & - & - & - & - & - & - & - & - & - & - & - \\
\hline Roe deer & $+\dagger$ & $+\ddagger$ & $21 \cdot 6$ & - & $+^{*}$ & - & - & - & - & - & - & - & - & - & - & - & - \\
\hline White-tailed deer & - & - & - & - & - & - & 4.7 & $27 \cdot 3$ & $24 \cdot 8$ & $4 \cdot 3$ & 22.5 & 13.5 & $75 \cdot 3$ & - & $90 \cdot 0$ & 98.0 & - \\
\hline Wild boars & $19 \cdot 3$ & $32 \cdot 1$ & $16 \cdot 0$ & - & $80 \cdot 8$ & - & - & - & - & - & - & - & - & - & - & - & - \\
\hline Unknown & 0.3 & - & - & + & - & - & - & - & - & - & - & - & - & - & - & - & - \\
\hline \multicolumn{18}{|l|}{ Non-ungulates } \\
\hline Beavers & $12 \cdot 6$ & $3 \cdot 1$ & - & 3.6 & - & $2 \cdot 1$ & $13 \cdot 2$ & $15 \cdot 1$ & $11 \cdot 1$ & 8.9 & $13 \cdot 6$ & 7.6 & - & $9 \cdot 0$ & 7.5 & - & + \\
\hline Bears & - & - & - & - & - & $5 \cdot 8$ & - & - & - & - & - & - & 0.4 & - & + & + & - \\
\hline Cats & - & - & - & - & - & - & - & - & - & - & - & - & - & - & - & - & - \\
\hline Dogs & + & - & - & - & - & - & - & - & - & - & - & - & - & - & - & - & + \\
\hline Hares or rabbits & 0.1 & - & 0.8 & $2 \cdot 5$ & - & - & + & + & + & $2 \cdot 3$ & 1.3 & 0.0 & 0.5 & 1.6 & 2.5 & $2 \cdot 0$ & 1.0 \\
\hline Insectivora|| & + & - & - & - & - & - & - & - & - & - & - & - & - & - & - & - & - \\
\hline Lynxף & - & - & - & - & - & - & - & - & - & - & - & - & - & - & + & + & - \\
\hline Medium-size ${ }^{\star \star}$ & 0.2 & 1.3 & - & - & - & - & - & - & - & - & - & - & - & + & + & + & - \\
\hline Mustelidae†† & + & - & - & - & - & 8.0 & - & - & - & - & - & - & - & - & + & + & + \\
\hline Rodentsł‡ & $2 \cdot 0$ & 1.1 & + & $2 \cdot 2$ & - & 0.7 & - & - & - & - & - & - & - & + & + & + & + \\
\hline Squirrels§§ & - & - & - & 0.1 & - & - & - & - & - & - & - & - & - & + & + & + & - \\
\hline Birds & 0.2 & - & + & + & - & + & - & - & - & - & - & - & 0.0 & + & - & - & - \\
\hline Reptiles & + & - & - & - & - & - & - & - & - & - & - & - & - & - & - & - & - \\
\hline Fish & - & - & + & - & - & + & - & - & - & - & - & - & - & + & - & - & - \\
\hline Intertidal organisms & - & - & - & - & - & + & - & - & - & - & - & - & - & - & - & - & - \\
\hline Insects & + & - & - & + & - & - & - & - & - & - & - & - & - & - & - & - & + \\
\hline Vegetation & 0.2 & 0.1 & - & + & - & + & - & - & _- & - & - & - & - & - & + & + & - \\
\hline Other & - & - & - & - & 4.5 & + & + & + & + & + & + & + & 0.3 & + & - & - & - \\
\hline Total & 99.4 & 98.9 & $100 \cdot 1$ & 99.9 & 100 & 99.9 & 100 & 100 & 99.9 & $102 \cdot 8$ & 102 & $92 \cdot 8$ & 100 & 99.9 & 100 & 100 & $97 \cdot 0$ \\
\hline
\end{tabular}


Table 2. Continued

\begin{tabular}{|c|c|c|c|c|c|c|c|c|c|c|c|c|c|c|c|c|c|}
\hline \multirow[t]{3}{*}{ Dietary item... } & \multicolumn{17}{|c|}{ Study no. } \\
\hline & \multirow{2}{*}{$\begin{array}{l}16 \\
W\end{array}$} & \multirow{2}{*}{$\begin{array}{l}17 \\
W\end{array}$} & \multirow[t]{2}{*}{18} & \multicolumn{3}{|c|}{20} & \multicolumn{3}{|c|}{24} & \multirow{2}{*}{$\begin{array}{l}25 \\
\mathrm{C}\end{array}$} & \multicolumn{2}{|c|}{26} & \multicolumn{3}{|c|}{28} & \multirow[t]{2}{*}{29} & \multirow[t]{2}{*}{30} \\
\hline & & & & $A$ & $\mathrm{~B}$ & $\mathrm{C}$ & $A$ & $\mathrm{~B}$ & $\mathrm{D}$ & & $A$ & $\mathrm{~B}$ & $\mathrm{~B}$ & $\mathrm{C}$ & $\mathrm{D}$ & & \\
\hline \multicolumn{18}{|l|}{ Mammals } \\
\hline \multicolumn{18}{|l|}{ Ungulates } \\
\hline Black-tailed deer & - & - & - & - & - & - & - & - & - & - & - & - & - & - & - & - & - \\
\hline Caribou & - & - & - & 21.3 & $25 \cdot 6$ & $17 \cdot 3$ & - & - & - & - & - & - & - & - & - & - & - \\
\hline European bison & - & 1.8 & - & - & - & - & - & - & - & - & - & - & - & - & - & - & - \\
\hline Fallow deer & - & - & - & - & - & - & - & - & - & 18.9 & - & - & - & $7 \cdot 0$ & $2 \cdot 0$ & - & - \\
\hline Livestock & - & 1.2 & 0.4 & - & - & - & 4.4 & 0.7 & $2 \cdot 6$ & 2.0 & - & - & - & - & - & + & - \\
\hline Moose & - & - & $1 \cdot 1$ & $76 \cdot 2$ & $69 \cdot 2$ & $80 \cdot 6$ & - & - & - & - & $67 \cdot 0$ & 86.0 & - & - & - & $64 \cdot 0$ & $97 \cdot 2$ \\
\hline Mouflon & - & - & - & - & - & - & - & - & - & 4.9 & - & - & - & - & - & - & - \\
\hline Mountain goats \|\| & - & - & - & - & - & - & - & - & - & - & - & - & - & - & - & - & - \\
\hline Red deer & 31.5 & - & $77 \cdot 2$ & - & - & - & - & - & - & 2.5 & - & - & 24.9 & $26 \cdot 7$ & $17 \cdot 8$ & - & - \\
\hline Roe deer & 2.9 & 3.9 & 1.8 & - & - & - & $19 \cdot 1$ & $18 \cdot 8$ & $10 \cdot 8$ & $14 \cdot 3$ & - & - & 42.9 & 33.1 & $57 \cdot 6$ & $26 \cdot 2$ & - \\
\hline White-tailed deer & - & - & - & - & - & - & - & - & - & - & + & + & - & - & - & - & - \\
\hline Wild boars & $7 \cdot 8$ & $12 \cdot 7$ & $9 \cdot 7$ & - & - & - & $58 \cdot 7$ & $70 \cdot 1$ & $79 \cdot 2$ & $49 \cdot 6$ & - & - & $16 \cdot 2$ & $26 \cdot 8$ & $19 \cdot 6$ & - & - \\
\hline Unknown & $56 \cdot 8$ & $69 \cdot 0$ & $8 \cdot 6$ & - & - & - & - & - & - & - & - & - & $5 \cdot 1$ & $3 \cdot 2$ & 0.9 & - & - \\
\hline \multicolumn{18}{|l|}{ Non-ungulates } \\
\hline Beavers & - & - & - & - & - & - & - & - & - & - & $21 \cdot 0$ & 8.0 & $5 \cdot 1$ & 0.3 & 0.1 & + & 1.0 \\
\hline Bears & - & - & - & - & - & - & - & - & - & - & - & - & - & - & - & - & - \\
\hline Cats & - & - & - & - & - & - & - & - & - & - & - & - & + & - & - & - & - \\
\hline Dogs & - & - & - & - & - & - & - & - & - & - & - & - & 1.6 & 0.8 & - & - & - \\
\hline Hares or rabbits & 0.2 & 0.1 & - & - & - & - & - & - & - & - & 1.0 & + & 3.2 & 1.9 & 1.8 & + & 1.8 \\
\hline Insectivora\| & - & 0.2 & - & - & - & - & - & - & - & - & - & - & + & - & - & - & - \\
\hline Lynxף & - & - & - & - & - & - & - & - & - & - & - & - & - & - & - & - & - \\
\hline Medium-size & 0.6 & 0.3 & 1.3 & - & - & - & - & - & - & + & + & + & 1.0 & 0.2 & - & $7 \cdot 8$ & + \\
\hline Mustelidae†† & - & - & - & - & - & - & - & - & - & - & - & - & - & - & 0.2 & - & - \\
\hline 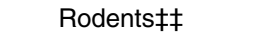 & + & $0 \cdot 1$ & - & - & - & - & - & - & - & $2 \cdot 2$ & + & + & + & + & + & + & + \\
\hline Squirrels§§ & + & - & - & - & - & - & - & - & - & - & $5 \cdot 0$ & $2 \cdot 0$ & + & - & - & - & - \\
\hline Birds & + & + & - & - & - & - & - & - & - & - & - & - & + & + & - & + & + \\
\hline Reptiles & + & + & - & - & - & - & - & - & - & - & - & - & - & - & - & - & - \\
\hline Fish & - & - & - & - & - & - & - & - & - & - & - & - & - & - & - & - & + \\
\hline Intertidal organisms & - & - & - & - & - & - & - & - & - & - & - & - & - & - & - & - & - \\
\hline Insects & + & - & - & - & - & - & - & - & - & 0.0 & - & - & - & - & - & - & + \\
\hline Vegetation & $0 \cdot 1$ & 0.1 & - & - & - & - & - & - & - & 0.0 & $2 \cdot 0$ & $3 \cdot 0$ & + & + & + & - & + \\
\hline Other & - & - & - & 2.5 & $5 \cdot 2$ & $2 \cdot 1$ & 4.7 & 3.0 & $5 \cdot 3$ & $2 \cdot 8$ & 4.0 & 1.0 & - & - & - & - & - \\
\hline Total & 99.9 & $100 \cdot 5$ & $100 \cdot 1$ & 100 & 100 & 100 & $86 \cdot 9$ & $92 \cdot 6$ & 97.9 & $97 \cdot 2$ & 100 & 100 & 100 & 100 & 100 & 98 & 100 \\
\hline
\end{tabular}




\section{N British Journal of Nutrition}

Table 2. Continued

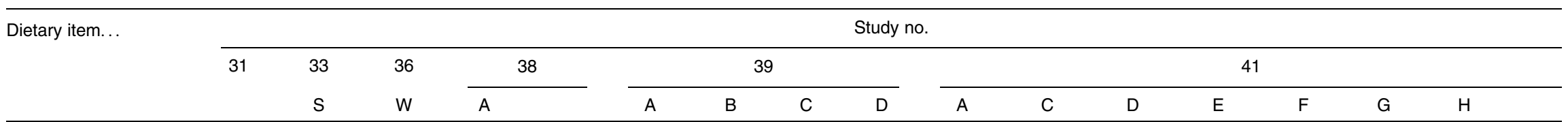

Mammals

Ungulates

Black-tailed deer

Caribou

European bison

Fallow deer

Livestock

Moose

Moose

Mountain goats|||

Red deer

Roe deer

White-tailed deer

Wild boars

Unknown

Non-ungulates

Beavers

Bears

Cats

Dogs

Hares or rabbits

Insectivoral|

Lynxף

Medium-size ${ }^{\star \star}$

Mustelidae††

Rodentsł‡

Squirrels§§

Birds

Reptiles

Fish

Intertidal organisms

Insects

Vegetation

Other

$\begin{array}{cccc}- & - & - & - \\ - & - & - & - \\ - & - & - & - \\ - & - & - & - \\ - & - & - & 3.7 \\ 82.9 & 44.5 & 16.0 & 32.5 \\ - & - & - & - \\ - & - & - & - \\ - & - & - & - \\ - & - & - & 3.6 \\ - & 13.5 & 80.5 & - \\ - & - & - & 52.3 \\ - & - & - & -\end{array}$

Total

$\begin{array}{cccc}16.6 & 36.5 & 2.0 & 3.3 \\ - & - & - & - \\ - & - & - & + \\ - & - & - & 0 \\ 0.4 & - & - & 2.2 \\ - & - & - & - \\ - & - & - & - \\ - & - & - & 0.9 \\ - & - & - & - \\ - & - & - & + \\ - & - & - & - \\ - & - & - & 0.9 \\ - & - & - & - \\ - & - & - & - \\ - & - & - & - \\ - & - & - & - \\ - & - & - & 0.3 \\ - & 5.5 & 1.5 & - \\ 99.9 & 100 & 100 & 100\end{array}$

$\begin{array}{ccccc}3.3 & 10.8 & 1.5 & 33.2 & 1.9 \\ - & - & 1.5 & 0.0 & 0.0 \\ + & - & - & - & \\ 0.3 & - & - & - & -1 \\ 2.2 & 0.8 & 0.2 & 0.0 & 0.1 \\ - & - & - & - & -2 \\ - & - & 0.0 & 0.2 \\ 0.9 & - & + & 0.0 & 0.3 \\ - & - & - & - \\ + & - & - & - & - \\ - & - & - & - & 0.0 \\ 0.9 & - & - & - \\ - & - & - & - \\ - & - & - & - \\ - & - & - & - \\ - & - & - & - & - \\ 0.3 & - & + & - & - \\ - & - & - & - & \\ 100 & 100.1 & 100.1 & 99.7 & 99.9\end{array}$

S, summer diet; W, winter diet: A-H, study details with regard to area and/or year (see Table 1); - food item was not mentioned; + , food item was present but not clearly quantified.

"Comprise together $14.2 \%$ of total biomass consumed; for further calculations, percentage of weight (PW) was equally divided across these species.

† Comprise together $62.2 \%$ of total biomass consumed; for further calculations, PW was equally divided across these species.

$\ddagger$ Comprise together $56.8 \%$ of total biomass consumed; for further calculations, PW was equally divided across these species.

$\S$ Comprise together $0.2 \%$ of total biomass consumed; for further calculations, PW was equally divided across these species.

$\|$ Also including shrews (Sorex araneus) and hedgehogs (Erinaceus spp.).

Includes bobcats (Lynx rufus) and Canadian lynx (Lynx canadensis).

** Including foxes (Vulpes spp.), porcupines (Erethizon dorsatum), raccoons (Procyon lotor), raccoon dogs (Nyctereutes procyonoides) and striped skunks (Mephitis mephitis).

†† Including badgers (Meles meles and Taxidea taxus), ermines (Mustela erminea), ferrets (Mustela putorius), martens (Martes spp.), minks (Mustela lutreola and Neovison vison), otters (Lutra lutra and Lontra canadensis) and weasels (Mustela nivalis).

¥¥ Including various species of the rodent family Cricetidae, e.g. microtins or voles (Microtus spp. and Myodes spp.), mice (Apodemus spp.) and muskrat (Ondatra zibethicus).

$\S \S$ Also including marmots (Marmota spp.).

III Also including chamois (Rupicapra spp.). 
(a) $80-$

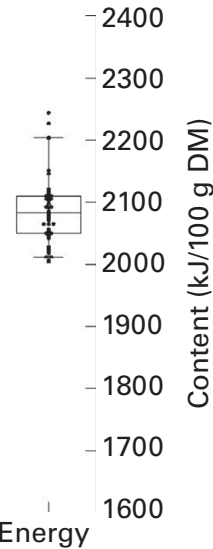

(b) 3.5
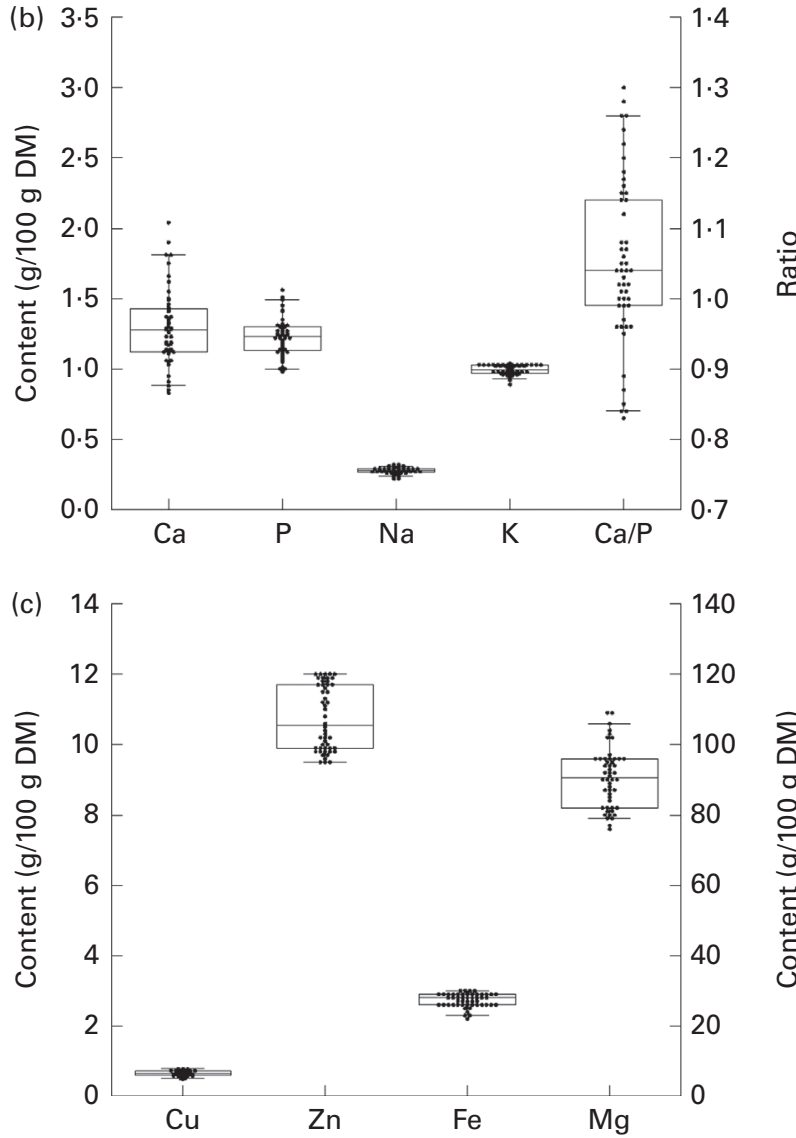

Fig. 1. Calculated macronutrient (a), micronutrient (b) and trace mineral (c) composition of the natural diet $(n 43)$ of wild wolves. The upper and lower hinges represent the 75 th and 25 th percentiles of the dataset. The band within the box represents the median. The whiskers extend to the $5 \%$ and $95 \% \mathrm{Cl}$. For (a), the calculated means are: DM, 38.6 (SEM 0.1 ) g/100 g; crude protein (CP), 67.2 (SEM 0.3) g/100 g DM; ethereal extract (EE), 24.9 (SEM 0.3) $\mathrm{g} / 100 \mathrm{~g} \mathrm{DM}$; nitrogen-free extract (NFE), 1.4 (SEM 0.0) g/100 g DM; ash, 6.4 (SEM 0.1) g/100 g DM; and energy, 2085 (SEM 8) kJ/100 g DM. For (b), the calculated means are: calcium, 1.30 (SEM 0.04) g/100 g DM; phosphorus, 1.23 (SEM 0.02) g/100 g DM; sodium, 0.28 (SEM 0.00) g/ $100 \mathrm{~g}$ DM; potassium, 0.99 (SEM 0.01) g/100 g DM; and calcium/phosphorus, 1.05 (SEM 0.02) $\mathrm{g} / 100 \mathrm{~g} \mathrm{DM}$. For (c) the calculated means are: copper, 0.66 (SEM 0.01 ) $\mathrm{mg} / 100 \mathrm{~g} \mathrm{DM}$; zinc, 10.8 (SEM 0.13 ) $\mathrm{mg} / 100 \mathrm{~g} \mathrm{DM}$; iron, 27.3 (SEM 0.3 ) $\mathrm{mg} / 100 \mathrm{~g} \mathrm{DM}$; and magnesium, 91 (SEM 1) $\mathrm{mg} / 100 \mathrm{~g} \mathrm{DM}$.
$\mathrm{Cu}, \mathrm{Zn}$ and Fe were $0 \cdot 66,10 \cdot 8$ and $27.3 \mathrm{mg} / 100 \mathrm{~g}$ DM, respectively. Dietary Mg varied between 76 and $109 \mathrm{mg} / 100 \mathrm{~g}$ DM with a mean value of $91 \mathrm{mg} / 100 \mathrm{~g} \mathrm{DM}$.

As the nutrient digestibility of most dietary items has not been described in the literature yet, it was not possible to take nutrient bioavailability into account. Considering the digestibility of the macronutrients, proteins are expected to vary most with the more digestible proteins being present in soft tissues (e.g. liver and large muscles) and poorly digestible proteins in bone and hide. The latter are consumed in the later stages of prey consumption ${ }^{(32)}$ or during scavenging ${ }^{(30)}$. With the organs and muscles contributing to the majority of the edible proportion of ungulate prey, most proteins may be considered to be well digestible and amino acids to be available for metabolism. Bone is one of the major nutrient sources of $\mathrm{Ca}$ and, to a lesser extent, $\mathrm{P}$ and $\mathrm{Mg}$, whereas other body tissues provide more than $95 \%$ of $\mathrm{Na}, \mathrm{K}, \mathrm{Cu}, \mathrm{Zn}$ and $\mathrm{Fe}$. For these nutrients, bioavailability is dependent not only on the dietary source but also on the nutritional status of the animal. When nutrient supply is limiting or excessive, absorption is up- or down-regulated by homeostatic mechanisms ${ }^{(41)}$. In general, the bioavailability of micronutrients and trace elements in soft animal tissues such as muscle and liver is higher than in vegetal sources ${ }^{(42)}$. Altogether, the nutrient profiles described provide the hitherto best estimates available for wild wolves but with the limitation that the bioavailability of these nutrients remains to be determined.

The selected protein-fat-carbohydrate profile of wolves in the present study (54:45:1\% by energy) is different from that in dogs, i.e. 30:63:7\% by energy ${ }^{(10)}$. Furthermore, profiles were similar between the five dog breeds studied (i.e. papillon, miniature schnauzer, cocker spaniel, Labrador retriever and St Bernard), indicating that the rapid divergence among dog breeds over the past 200 years was not substantially reflected in the macronutrient priorities among the modernday breeds of dogs ${ }^{(10)}$. Hewson-Hughes et al. $^{(10)}$ attributed the lipid selection of dogs to the early domestication period when dogs became 'adapted' to a human-associated diet. During this period, such a diet would have consisted of human-derived vegetal and animal food waste items ${ }^{(3)}$. Furthermore, commensal species such as rodents may have been a food source for early dogs, as it is (a small) part of many diets for wolves (see Table 2). It is beyond the scope of the present study to consider possible waste items from human settlements, but it would be unlikely that huntergatherers disposed such lipid-rich food items when famines and seasonal food shortages were common in those agricultural societies ${ }^{(43,44)}$ as the intake of energy from lipids would have been vital for survival. The preference of dogs for lipid-rich diets may thus be a trait that has evolved during the evolution of its ancestor the wolf rather than during early dog domestication.

\section{Fluctuating food availability}

Wolves are carnivores that cope with distinct periods of feast and famine, which is different from the ecology of wildcats. These profound fluctuations in food availability have resulted 
in different coping strategies by wolves. As indicated earlier, wolves hunt in packs on large ungulates and opportunistically scavenge a varied but essentially animal-based diet. During periods of abundant prey availability, wolves ingest large amounts of highly nutritious animal tissues, with a feast meal weight of up to $22 \%$ of their body weight (BW), and a preferential consumption of internal organs such as liver ${ }^{(30)}$. During prolonged periods of low prey availability, a pack of wolves may go days without catching large prey during which time they consume smaller prey and some leftovers of old prey ${ }^{(33)}$. Wolves have been observed to scavenge on bone and hide for even up to 10 weeks ${ }^{(30)}$. Wolves also consume prey parts they cached for later consumption $^{(45-47)}$. When food is available, wolves can quickly recover again from weight loss during fasting. Captive (sedentary) wolves fasted for $10 \mathrm{~d}$ lost $7-8 \%$ of their BW, which was replenished after $2 \mathrm{~d}$ of consuming white-tailed deer meat with amounts between 15 and $19 \%$ of their BW per $\mathrm{d}^{(48)}$. Also dogs can resist prolonged periods of famine. An adult Scotch collie named 'Oscar' has the longest fast on record; after an astonishing $117 \mathrm{~d}$ and weighing only $37 \%$ of its initial BW, the fast was stopped ${ }^{(49)}$. In contrast, wildcats (Felis silvestris), the domestic cat's ancestor ${ }^{(50)}$, are predominantly solitary and hunt individually catching a variety of mainly small mammals and birds weighing only approximately $1 \%$ of their $\mathrm{BW}^{(51)}$. Wildcats, therefore, require multiple small prey items per $\mathrm{d}$ and thrive in habitats abundant in prey year-round.

During times of low food availability, dogs have been shown to very effectively utilise body fat resources for energy purposes. de Bruijne \& van den Brom $^{(52)}$ found that peripheral utilisation of ketone bodies in fasting dogs was very efficient. It was estimated that the contribution of ketone bodies to the daily energy requirement of dogs increased from $7 \%$ in the overnight-fasted state to $13 \%$ after $10 \mathrm{~d}$ of starvation. Also, the capacity to decrease metabolic losses and to endogenously synthesise essential nutrients for ongoing metabolic processes will be vital for survival and, as such, has been conserved throughout evolution. Wolves efficiently conserve body proteins by down-regulating enzymes involved in amino acid catabolism to cope with famine ${ }^{(53)}$. Such protein sparing capacity is also observed in other carnivores that face prolonged periods of famine such as polar bears (U. maritimus) ${ }^{(54)}$, Antarctic fur seal (Arctocephalus gazella) pups ${ }^{(55)}$ and chicks of king penguins (Aptenodytes patagonica) $^{(56)}$. Cats, on the contrary, are less capable of conserving protein as they maintain high activities of amino acid catabolising enzymes for gluconeogenesis ${ }^{(57)}$. This difference becomes apparent when fed a diet without protein; adult dogs produce half as much urinary urea as cats $\left(116 v .243 \mathrm{mg} / \mathrm{kg}^{0.75} \text { per } \mathrm{d}\right)^{(58)}$. The feline feeding ecology with regular nutrient intake relaxed selection pressures for conserving certain metabolic pathways, which is reflected by low enzymatic synthesis capacity of cats for a number of nutrients (e.g. niacin, taurine, arginine and arachidonic acid) ${ }^{(57)}$. It can be hypothesised that other large carnivores with a feast-or-famine lifestyle such as polar bears, cougars (Puma concolor), lions (Panthera leo) or pinnipeds also have capacities to synthesise essential nutrients such as arginine and niacin or may have developed other metabolic strategies that are key for their survival.

As mentioned earlier, the strong preference for lipids shown by $\operatorname{dogs}^{(10)}$ could also be linked to the feeding ecology of wolves. Preferential lipid intake by wolves at times of prey abundance increases adipose tissue that serves as an energy store for periods of low prey abundance. The importance of lipid intake may also be reflected in the preservation of post-carnassial molars in wolves (and dogs) during evolution. These molars are used to crush large bones ${ }^{(59)}$ and provide access to the lipid-rich marrow (see online supplementary Table S3). The extent of seasonal fasting in nature may also explain why mink (Mustela vison), which preys on small animals such as wildcats and encounter periods of famine ${ }^{(60)}$, selects an intermediate diet containing 35\% protein and $50 \%$ lipid by energy ${ }^{(61)}$. This latter observation, however, requires further study as it may merely reflect the selection for macronutrients as in their normal diet fed over generations ${ }^{(61)}$. Macronutrient profiling of other carnivorous species varying in lifestyle might provide insight if profiles can be linked to the extent of seasonal fasting in nature.

At times of feast, when large ungulates are killed, wolves in general rapidly open the body cavity and consume the internal organs such as the heart, lungs, liver, spleen and kidneys ${ }^{(30)}$. The liver of an ungulate would provide stored vitamin A and potentially glycogen. Dogs transport vitamin A as retinyl esters in the blood and clear blood retinyl through the kidney ${ }^{(62)}$, which makes them more resistant to hypervitaminosis A and can be considered as functional for wolves. Although it is unclear what proportion of the glycogen stores remains after the chase and catch of the prey, intestinal amylase and hepatic glucokinase activities as present in domestic dogs would be functional for glycogen utilisation. Furthermore, liver contains glycogen that, like starch from plants, can be digested and utilised by the use of intestinal amylase and hepatic glucokinase. The higher activities of these enzymes in dogs than in cats ${ }^{(63,64)}$ may be consistent with a diet periodically high in liver and muscle tissue rather than a diet high in plant starch.

Dogs share numerous typical carnivorous characteristics with cats (see Fig. 2). For example, both species lack salivary amylase, have a short and simple gastrointestinal tract, conjugate bile acids with taurine and are unable to synthesise vitamin $\mathrm{D}^{(12)}$. The metabolic adaptations, such as protein sparing and endogenous niacin synthesis capacity, facilitating survival during times of low dietary nutrient availability are similar to those observed in omnivores, and this may be a key factor to explain differences in digestive physiology and metabolism between today's domestic dogs and cats. Omnivores, such as pigs and rats, may not experience similar periods of famine like wolves but more specifically encounter fluctuations in amounts and types of vegetal and animal matter in their diets (e.g. due to season). The omnivorous pig and rat, consuming lower and fluctuating amounts of protein due to seasonal changes in availability of vegetal and animal matter, can reduce urea excretion even further to 70 and $60 \mathrm{mg} / \mathrm{kg}^{0.75}$ per $\mathrm{d}^{(58)}$, respectively. It can be speculated that 


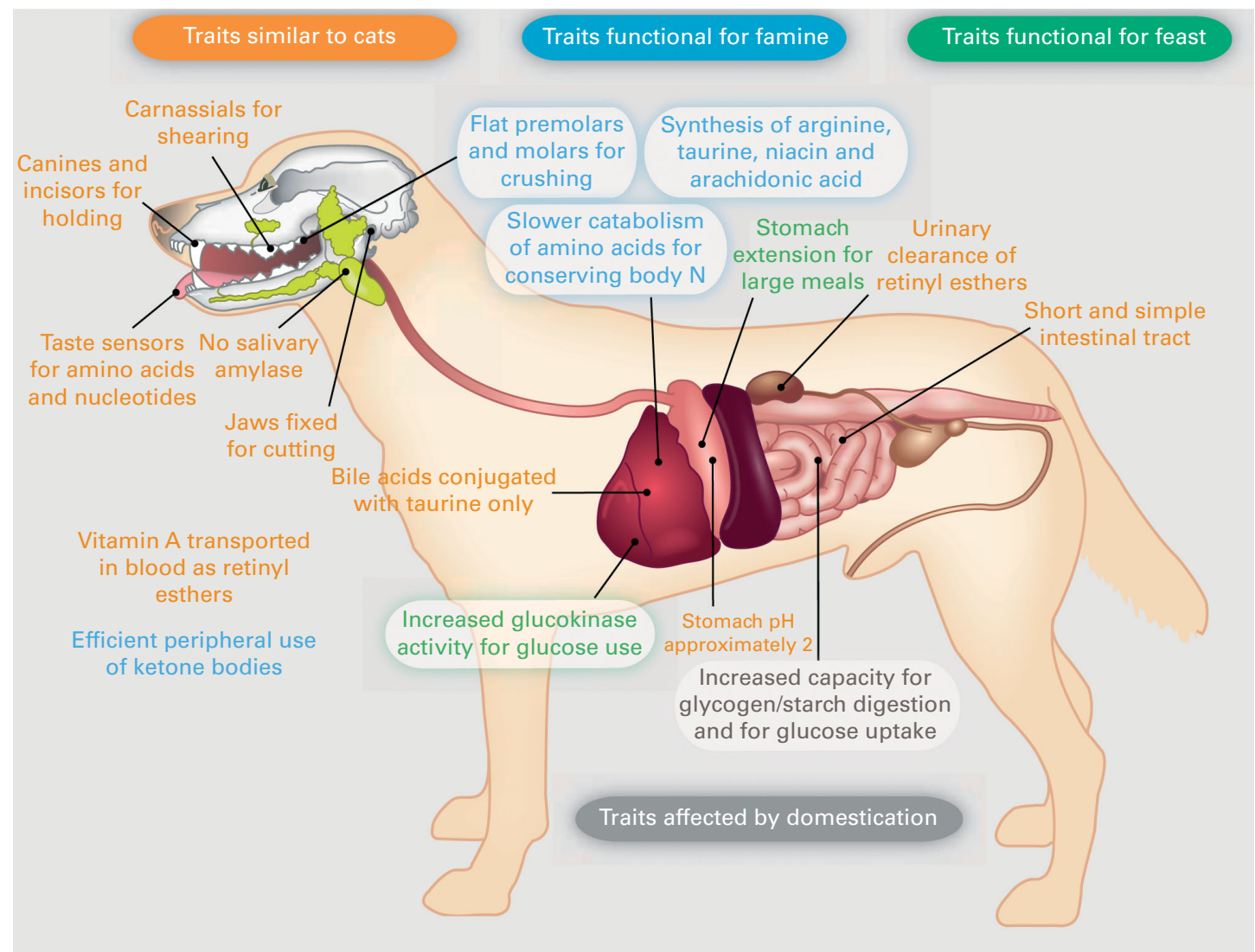

Fig. 2. Omnivorous dog traits revisited. Dogs are classified as omnivores based on traits that are different from carnivorous cats. The authors hypothesise that these 'omnivorous' traits, highlighted in white boxes, reflect the typical feast-or-famine lifestyle of the carnivorous dog's ancestor, the wolf. Traits outlined in green and blue are functional for periods of feast and famine, respectively. Dogs share numerous traits with cats, shown in orange. Capacities of traits shown in grey are the target during domestication ${ }^{(7)}$.

the array of metabolic traits shaped by a feast-or-famine lifestyle enabled carnivorous wolves to metabolically thrive on relatively lower-nutritious human food wastes. These wolves were likely already capable of utilising the starch from plants. Glycogen stored in muscles and in particular liver from prey is, after consumption by carnivores, processed similarly using pancreatic amylase, small intestinal GLUT and hepatic glucokinase. Those dogs with genetic mutations in the $A M Y 2 B, M G A M$ and SGLT1 genes were more fit to this new niche opened up by $\operatorname{man}^{(7)}$. Furthermore, this niche

Table 3. Approximated dietary nutrient profiles reported in the literature of wild wolves, profiles as affected by a wolf's ranking and during scavenging, and minimal and recommended allowance (RA) nutrient composition for dogs in growth and at maintenance

\begin{tabular}{|c|c|c|c|c|c|c|c|c|}
\hline \multirow[b]{3}{*}{ Item } & \multirow[b]{3}{*}{ Unit } & \multirow[b]{3}{*}{ Wolf* } & \multicolumn{4}{|c|}{ National Research Council ${ }^{(12)}$} & & \\
\hline & & & \multicolumn{2}{|c|}{ Growth } & \multicolumn{2}{|c|}{ Maintenance } & \multicolumn{2}{|c|}{ Commercial $^{(66)}$} \\
\hline & & & Minimum & $\mathrm{RA}$ & Minimum & RA & Dry & Moist \\
\hline ME & $\mathrm{kJ} / 100 \mathrm{~g} \mathrm{DM}$ & 2085 & & & & & 1745 & 1849 \\
\hline $\mathrm{CP}$ & g/MJ ME & $32 \cdot 2$ & $10 \cdot 8$ & $13 \cdot 5$ & $4 \cdot 8$ & $6 \cdot 0$ & $16 \cdot 1$ & $17 \cdot 4$ \\
\hline EE & $\mathrm{g} / \mathrm{MJ} \mathrm{ME}$ & 11.9 & & $5 \cdot 1$ & & 3.3 & $9 \cdot 3$ & $12 \cdot 0$ \\
\hline NFE & g/MJ ME & 0.7 & & & & & $25 \cdot 8$ & $20 \cdot 0$ \\
\hline $\mathrm{Ca}$ & $\mathrm{g} / \mathrm{MJ} \mathrm{ME}$ & 0.62 & 0.48 & 0.72 & 0.12 & 0.24 & 0.76 & 0.65 \\
\hline $\mathrm{P}$ & $\mathrm{g} / \mathrm{MJ} \mathrm{ME}$ & 0.59 & & 0.60 & & 0.18 & 0.58 & 0.50 \\
\hline $\mathrm{Na}$ & $\mathrm{g} / \mathrm{MJ} \mathrm{ME}$ & 0.13 & & 0.13 & 0.02 & 0.05 & 0.24 & 0.29 \\
\hline K & g/MJ ME & 0.48 & & 0.26 & & 0.24 & 0.40 & 0.48 \\
\hline $\mathrm{Cu}$ & $\mathrm{mg} / \mathrm{MJ} \mathrm{ME}$ & 0.32 & & 0.65 & & 0.36 & NA & NA \\
\hline $\mathrm{Zn}$ & mg/MJ ME & $5 \cdot 2$ & $2 \cdot 4$ & $6 \cdot 0$ & & 3.6 & NA & NA \\
\hline $\mathrm{Fe}$ & mg/MJ ME & $13 \cdot 1$ & $4 \cdot 3$ & $5 \cdot 3$ & & 1.8 & NA & NA \\
\hline $\mathrm{Mg}$ & $\mathrm{mg} / \mathrm{MJ} \mathrm{ME}$ & 43.4 & $10 \cdot 8$ & 23.9 & $10 \cdot 8$ & 35.9 & $68 \cdot 8$ & $54 \cdot 1$ \\
\hline
\end{tabular}

$\mathrm{ME}$, metabolisable energy; $\mathrm{CP}$, crude protein; $\mathrm{EE}$, ethereal extract; NFE, N-free extract; NA, not available. ${ }^{*}$ Average dietary profiles reported in the literature ( $n 50$, see Table 2$)$. 
favoured wolves smaller in body size, which required less energy, and those more tolerant to human proximity ${ }^{(65)}$

\section{Comparison with dog nutrition}

The wolf's natural dietary nutrient profile differs in several aspects from the nutrient guidelines and in nutritive characteristics of commercial foods. Table 3 provides the average dietary nutrient profile for wild wolves (based on $n 50$ diets) reported in the present study (in units/MJ metabolisable energy (ME)) compared to the minimum nutrient requirement of growing dogs and of dogs at maintenance as provided by the National Research Council ${ }^{(12)}$. The physiological minimum nutrient requirement have been accurately determined for several nutrients and can be considered to represent the limit of the adaptation capacity of domestic dogs in relation to dietary nutrient concentrations ${ }^{(11)}$. Contents of crude protein, $\mathrm{Ca}, \mathrm{Zn}, \mathrm{Fe}$ and $\mathrm{Mg}$ in the average wolf diet are well above the set minimum nutrient requirement for these nutrients, although the bioavailability of these nutrients is unknown.

The recommended allowance set by National Research Council ${ }^{(12)}$ for dietary $\mathrm{Ca}$ for growth and $\mathrm{Cu}$ for growth and maintenance is higher than that found in the average diet of wolves (Table 3). Furthermore, the average $\mathrm{Ca}$ content of the wolf's diet is lower than that found in commercial dry foods, and the wolf's dietary $\mathrm{Na}$ and $\mathrm{Mg}$ contents are lower than the average for commercial dry and moist dog foods. It should be noted, however, that due to higher energy requirements, the actual daily nutrient intake of wolves is higher than that of the average sedentary pet dog living in a temperate environment. The daily energy requirement of adult wolves ( $35 \mathrm{~kg} \mathrm{BW}$ ) has been estimated to be $25025 \mathrm{~kJ} \mathrm{ME}^{(29)}$ or $1739 \mathrm{~kJ} / \mathrm{kg}^{0.75} \mathrm{BW}$, which is 3.2 times higher than the daily energy requirements for the maintenance of adult dogs $\left(544 \mathrm{~kJ} / \mathrm{kg}^{0.75} \mathrm{BW}\right)^{(12)}$. Thus, the actual daily intake of micronutrients and trace elements included in the profile would be higher in wild wolves than in pet dogs fed foods with nutrient contents close to the recommended allowance values and fed the average commercial foods reported in Table 3. Little information is available about how nutrient requirements vary with energy expenditure in $\operatorname{dogs}{ }^{(12)}$, but it is reasonable to assume that the increase in energy requirements for physical activity and thermoregulation does not result in an equal increase in reported micronutrients and trace elements. Hence, the wolf's metabolism may be accustomed to high dietary availability of these nutrients.

The nutritive characteristics of commercial foods may differ in several aspects from the wolf's natural dietary nutrient profile, and this may pose physiological and metabolic challenges that dogs need to cope with. The average nutrient composition of commercial high-quality dry extruded ( $n$ 93) and moist canned ( $n$ 39) dog foods ${ }^{(66)}$ is presented in Table 3. The average dietary NFE content of dogs fed dry and moist commercial foods is substantially higher (25.8 and $20.0 \mathrm{~g} / \mathrm{MJ}$ ME, respectively) than the dietary NFE content of wolves $(0.7 \mathrm{~g} / \mathrm{MJ} \mathrm{ME})$. The NFE content in dog foods mainly originates from the starch of cereal grains. These starches are cooked during processing and are, therefore, generally well digested by dogs, with ileal apparent digestibility reaching values of above $99 \%$ for starches in dry extruded diets ${ }^{(67)}$. For wolves, the NFE intake would be conditionally high and in the form of glycogen, i.e. when a liver of a large prey, containing approximately $10.5 \mathrm{~g} / \mathrm{MJ} \mathrm{ME}$ in a white-tailed deer ${ }^{(68)}$ (see also later texts), is consumed. To the authors' knowledge, the glycaemic index of glycogen is unknown, but wolves are not likely to be exposed to a daily glycaemic load that pet dogs fed commercial dry and wet foods may experience. Although the dog has been shown to have an increased digestive and absorptive capacity to cope with starch-containing foods compared to wolves, the impact of a consistent high amount of absorbed glucose on the dog's health and longevity remains to be determined.

The average content of EE of the wolf's diet was slightly higher than the average content normally observed in commercial foods. The origin of lipids in both diets, however, would also be different resulting in a different fatty acid profile consumed. Dog foods contain lipids from vegetable oil (e.g. soyabean, sunflower and maize) and/or animal origin (e.g. pork fat, beef tallow, poultry fat and fish oil). Lipids from vegetable origin are typically higher in $n-6$ PUFA than in $n-3$ PUFA. In addition, with regard to the $n$-3 PUFA, vegetable oils are relatively rich in $\alpha$-linolenic acid $(18: 3 n-3)$ whereas those from animal origin are typically high in EPA $(20: 5 n-3)$ and DHA (22:6n-3). The PUFA profile lipids derived from animals vary according to diets fed during rearing. The $n-6: n-3$ ratios in muscle lipids of cattle and chickens raised in captivity range between $6: 1$ and 19:1 ${ }^{(69)}$ whereas those for wild mule deer and red deer contain a ratio of approximately $2: 1$ to $3: 1^{(70)}$, closely matching the ratio of $2: 1$ of wolf subcutaneous fat ${ }^{(71)}$. Also, modern aquaculture produces fish that contain less $n$-3 PUFA than do their wild counterparts, although the $n-6: n-3$ ratio is still very low (1:6 for cultured and 1:11 for wild salmon (Salmo salar) ${ }^{(72)}$ ). The vegetable and animal lipid sources commonly used in dog foods result in higher $n-6: n-3$ ratio than that of lipids from wild animals. Commercial dog foods ( $n$ 12) showed an average $n-6: n-3$ ratio of $8: 1$, ranging from 5:1 to $17: 1^{(73)}$. Furthermore, the average PUFA concentration in the lipid fraction of these dog foods was $24.4 \%$ (range $18 \cdot 1-43 \cdot 1 \%)^{(73)}$, which is lower than 31.3 and $28.7 \%$ PUFA content in muscle lipids of mule deer and red deer, respectively ${ }^{(70)}$. Considering the involvement of $n$-3 PUFA (EPA and DHA) in numerous physiological processes, including the mediation of inflammatory and immune responses, renal functioning, cardiovascular health and neurologic development ${ }^{(72,74-76)}$, the fatty acid profiles of our pet dog foods deserves careful (re)consideration. The impact of a relative shortage of $n-3$ fatty acids in the commercial diet on the functioning immune system of dogs requires further study.

Undigested dietary fractions provide substrates for the microbiota in the distal small and large intestine and the type of substrates can be expected to differ between those of a wolf's diet and dry and moist dog foods. Whole prey and, specifically, lower-quality animal tissues (e.g. hide and bones) provide low digestible or indigestible substances such as cartilage, collagens and glycosaminoglycans, with 
specific fermentative characteristics ${ }^{(77)}$ other than fibres of vegetal origin and indigestible proteins in processed foods. Given the involvement of the intestinal microbial community in host physiology, immune function and behaviour ${ }^{(78)}$, the effect of these specific substances on the canine microbial composition and activity and on canine (intestinal) health warrants further investigation.

The concept of 'natural' foods that may better match the physiological and metabolic make-up of dogs is comparable to the paradigm that the Palaeolithic hunter-gatherer diet would better fit modern man than our current nutrition. The discordance hypothesis originally described by Eaton \& Konner $^{(37,79)}$ states that the human genome evolved to adapt to conditions that no longer exist, the change from Palaeolithic to current nutrition occurred too rapidly for adequate genetic adaptation and the resulting mismatch helps to cause some common 'diseases of civilisation' such as diabetes mellitus, obesity and dental disease ${ }^{(80)}$. Furthermore, the nutrient intake of modern-day hunter-gatherers is suggested to represent a reference standard for modern human nutrition and a model for defence against these diseases. To what extent the discordance hypothesis may also apply for dogs and to what extent the nutrient profile of the wolf's diet is optimal for pet dogs are subjects for study. The nutrient profile described here originates from a wolf population living under severe physiological and climatic conditions and in which nutrition is a precondition for species survival and procreation. In general, our domestic dogs have a much more sedentary lifestyle, regular meals and a longer lifespan, which may have a significant effect on nutrient requirements and handling. Dogs have adapted to a starch-rich diet (i.e. increased enzymatic capacity to digest starch and increased glucose uptake capacity) and are able to cope with large variations in nutrient intake. There are also situations of reduced adaptation capacity (such as geriatrics and chronic disease) in which the consumption of a diet that requires an adaptable metabolism may place the animal under stress. Nevertheless, the wolves' feeding ecology and nutrient intake may provide valuable information to further improve our understanding of the origin of the dogs' digestive physiology and metabolism and possibly provide new leads for optimising individual health and longevity.

\section{Conclusions and implications}

Data on the wolf's feeding ecology show that the progenitors of our modern-day dogs were adaptive, true carnivores and not omnivores. During times of feast and famine, wolves would have had to cope with a variable nutrient intake requiring an adaptable metabolism, which is still functional in our modern-day dogs. These traits may also allow wolves to make the transition from carnivory to omnivory during domestication. The nutritive characteristics of commercial foods differ in several aspects from the dog's closest free-living progenitor in terms of dietary nutrient profile, and this may pose physiological and metabolic challenges that dogs need to cope with. The question remains to what extent the approximated nutrient profile also optimally supports health and longevity of domestic dogs with a more sedentary lifestyle and a longer lifespan in a different environment. The present study describing the wolf's dietary nutrient profile may provide an impetus for further research in this area similar to research activities in the field of human nutrition ${ }^{(79)}$. Laboratory, clinical and epidemiological studies would be required in which the nutrient profile and other aspects of a wolf's diet are translated and evaluated for their contribution to the health and longevity in today's pet dogs.

\section{Supplementary material}

To view supplementary material for this article, please visit http://dx.doi.org/10.1017/S0007114514002311

\section{Acknowledgements}

This research was funded by Wageningen University and Utrecht University. All authors contributed fundamentally to the present manuscript. G. B. contributed to all facets including research design, data collection, calculations and writing the initial manuscript. E. A. H.-P. and W. H. H. contributed to research design, data interpretation and manuscript preparation. The authors thank David L. Mech for his willingness to answer the questions relating to the feeding ecology of wolves. Laura de Vries, Gijs Hulsebosch, Joyce Neroni and Esther Lichtenberg are thanked for their contributions at the beginning of this research. There are no conflicts of interest.

\section{References}

1. Clutton-Brock J (1995) Origins of the dog: domestication and early history. In The Domestic Dog: Its Evolution, Behaviour and Interactions with People, pp. 7-20 [JA Serpell, editor]. Cambridge, UK: Cambridge University Press.

2. Driscoll CA, Macdonald DW \& O'Brien SJ (2009) From wild animals to domestic pets, an evolutionary view of domestication. Proc Natl Acad Sci U S A 106, 9971-9978.

3. Driscoll CA \& MacDonald DW (2010) Top dogs: wolf domestication and wealth. $J$ Biol 9, 10.

4. VonHoldt BM, Pollinger JP, Lohmueller KE, et al. (2010) Genome-wide SNP and haplotype analyses reveal a rich history underlying dog domestication. Nature $\mathbf{4 6 4}$ 898-902.

5. Boyko AR, Quignon P, Li L, et al. (2010) A simple genetic architecture underlies morphological variation in dogs. PLoS Biol 8, e1000451.

6. Vilà C \& Wayne RK (1999) Hybridization between wolves and dogs. Conserv Biol 13, 195-198.

7. Axelsson E, Ratnakumar A, Arendt ML, et al. (2013) The genomic signature of dog domestication reveals adaptation to a starch-rich diet. Nature 495, 360-364.

8. Freedman AH, Gronau I, Schweizer RM, et al. (2014) Genome sequencing highlights the dynamic early history of dogs. PLoS Genet 10, e1004016.

9. Hewson-Hughes AK, Hewson-Hughes VL, Colyer A, et al. (2013) Consistent proportional macronutrient intake selected by adult domestic cats (Felis catus) despite variations in macronutrient and moisture content of foods offered. J Comp Physiol B 183, 525-536.

10. Hewson-Hughes AK, Hewson-Hughes VL, Colyer A, et al. (2013) Geometric analysis of macronutrient selection in 
breeds of the domestic dog, Canis lupus familiaris. Behav Ecol 24, 293-304.

11. Plantinga EA, Bosch G \& Hendriks WH (2011) Estimation of the dietary nutrient profile of free-roaming feral cats: possible implications for nutrition of domestic cats. Br J Nutr 106, S35-S48.

12. NRC (2006) Nutrient Requirements of Dogs and Cats. Washington, DC: National Academies Press

13. Hand MS, Thatcher CD, Remillard RL, et al. (editors) (2010) Small Animal Clinical Nutrition, 5th ed. Topeka, KS: Mark Morris Institute.

14. Andersone Z \& Ozolinš J (2004) Food habits of wolves Canis lupus in Latvia. Acta Theriol 49, 357-367.

15. Darimont CT, Price MHH, Winchester NN, et al. (2004) Predators in natural fragments: foraging ecology of wolves in British Columbia's central and north coast archipelago. J Biogeogr 31, 1867-1877.

16. Fritts SH \& Mech LD (1981) Dynamics, movements, and feeding ecology of a newly protected wolf population in Northwestern Minnesota. Wildl Monogr 80, 3-79.

17. Jedrzejewski W, Jedrzejewska B, Okarma H, et al. (2000) Prey selection and predation by wolves in Białowieża Primeval Forest, Poland. J Mammal 81, 197-212.

18. Peterson RO (1977) Wolf ecology and prey relationships on Isle Royale. PhD Thesis, Purdue University, West Lafayette, IN

19. Fuller TK (1989) Population dynamics of wolves in NorthCentral Minnesota. Wildl Monogr 105, 1-41.

20. Gade-Jørgensen I \& Stagegaard R (2000) Diet composition of wolves Canis lupus in east-central Finland. Acta Theriol 45, 537-547.

21. Tremblay J-P, Jolicoeur H \& Lemieux R (2001) Summer food habits of gray wolves in the boreal forest of the Lac Jacques-Cartier highlands, Québec. Alces 37, 1-12.

22. Wagner C, Holzapfel M, Kluth G, et al. (2012) Wolf (Canis lupus) feeding habits during the first eight years of its occurrence in Germany. Mamm Biol 77, 196-203.

23. Meriggi A, Brangi A, Matteucci C, et al. (1996) The feeding habits of wolves in relation to large prey availability in northern Italy. Ecography 19, 287-295.

24. Bradshaw JW (2006) The evolutionary basis for the feeding behavior of domestic dogs (Canis familiaris) and cats (Felis catus). J Nutr 136, S1927-S1931.

25. Derocher AE, Andriashek D \& Stirling I (1993) Terrestrial foraging by polar bears during the ice-free period in western Hudson Bay. Arctic 46, 251-254.

26. Iversen M, Aars J, Haug T, et al. (2013) The diet of polar bears (Ursus maritimus) from Svalbard, Norway, inferred from scat analysis. Polar Biol 36, 561-571.

27. Platt SG, Elsey RM, Liu H, et al. (2013) Frugivory and seed dispersal by crocodilians: an overlooked form of saurochory? J Zool 291, 87-99.

28. Bump JK, Peterson RO \& Vucetich JA (2009) Wolves modulate soil nutrient heterogeneity and foliar nitrogen by configuring the distribution of ungulate carcasses. Ecology 90, 3159-3167.

29. Peterson RO \& Ciucci P (2003) The wolf as a carnivore In Wolves: Behavior, Ecology, and Conservation, pp. 104-111 [LD Mech and L Boitani, editors]. Chicago, IL: University of Chicago Press.

30. Stahler DR, Smith DW \& Guernsey DS (2006) Foraging and feeding ecology of the gray wolf (Canis lupus): lessons from Yellowstone National Park, Wyoming, USA. J Nutr 136, S1923-S1926.
31. Potvin F, Jolicoeur H \& Huot J (1988) Wolf diet and prey selectivity during two periods for deer in Quebec: decline versus expansion. Can J Zool 66, 1274-1279.

32. Wilmers CC, Crabtree RL, Smith DW, et al. (2003) Trophic facilitation by introduced top predators: grey wolf subsidies to scavengers in Yellowstone National Park. J Anim Ecol 72, 909-916.

33. Mech LD (1970) The Wolf: The Ecology and Behavior of an Endangered Species. Garden City, NY: The Natural Histroy Press.

34. Remonti L, Balestrieri A \& Prigioni C (2011) Percentage of protein, lipids, and carbohydrates in the diet of badger (Meles meles) populations across Europe. Ecol Res 26, 487-495.

35. Potter MA, Hendriks WH, Lentle RG, et al. (2010) An exploratory analysis of the suitability of diets fed to a flightless insectivore, the North Island brown kiwi (Apteryx mantelli), in New Zealand. Zoo Biol 29, 537-550.

36. Eaton SB, Eaton SB III \& Konner MJ (1997) Paleolithic nutrition revisited: a twelve-year retrospective on its nature and implications. Eur J Clin Nutr 51, 207-216.

37. Eaton SB \& Konner M (1985) Paleolithic nutrition. A consideration of its nature and current implications. $N$ Engl J Med 312, 283-289.

38. Kuipers RS, Luxwolda MF, Dijck-Brouwer JDA, et al. (2010) Estimated macronutrient and fatty acid intakes from an East African Paleolithic diet. Br I Nutr 104, 1666-1687.

39. Cordain L, Miller JB, Eaton SB, et al. (2000) Plant-animal subsistence ratios and macronutrient energy estimations in worldwide hunter-gatherer diets. Am J Clin Nutr 71, 682-692.

40. Eaton SB (2006) The ancestral human diet: what was it and should it be a paradigm for contemporary nutrition? Proc Nutr Soc 65, 1-6.

41. Fairweather-Tait S, Hurrell RF, Van Dael P, et al. (1996) Bioavailability of minerals and trace elements. Nutr Res Rev 9, 295-324.

42. Nohr D \& Biesalski HK (2007) 'Mealthy' food: meat as a healthy and valuable source of micronutrients. Animal $\mathbf{1}$, 309-316.

43. Prentice AM (2001) Fires of life: the struggles of an ancient metabolism in a modern world. Nutr Bull 26, 13-27.

44. Prentice AM, Rayco-Solon P \& Moore SE (2005) Insights from the developing world: thrifty genotypes and thrifty phenotypes. Proc Nutr Soc 64, 153-161.

45. Mech LD and Boitani L (editors) (2003) Wolves: Behavior, Ecology, and Conservation. Chicago, IL: University of Chicago Press.

46. Harrington FH (1981) Urine-marking and caching behavior in the wolf. Behaviour 76, 280-288.

47. Phillips DP, Danilchuk W, Ryon J, et al. (1990) Foodcaching in timber wolves, and the question of rules of action syntax. Behav Brain Res 38, 1-6.

48. Kreeger TJ, DelGiudice GD \& Mech LD (1997) Effects of fasting and refeeding on body composition of captive gray wolves (Canis lupus). Can J Zool 75, 1549-1552.

49. Howe PE, Mattill HA \& Hawk PB (1912) Distribution of nitrogen during a fast of one hundred and seventeen days. J Biol Chem 11, 103-127.

50. Driscoll CA, Menotti-Raymond M, Roca AL, et al. (2007) The Near Eastern origin of cat domestication. Science 317, 519-523.

51. Pearre S \& Maass R (1998) Trends in the prey size-based trophic niches of feral and house cats Felis catus L. Mammal Rev 28, 125-139. 
52. de Bruijne JJ \& van den Brom WE (1986) The effect of long-term fasting on ketone body metabolism in the dog. Comp Biochem Physiol B 83, 391-395.

53. Kreeger TJ (2003) The internal wolf: physiology, pathology, and pharmacology. In Wolves: Behavior, Ecology, and Conservation, pp. 192-217 [LD Mech and L Boitani, editors]. Chicago, IL: University of Chicago Press.

54. Derocher AE, Nelson RA, Stirling I, et al. (1990) Effects of fasting and feeding on serum urea and serum creatinine levels in polar bears. Mar Mammal Sci 6, 196-203.

55. Arnould JPY, Green JA \& Rawlins DR (2001) Fasting metabolism in Antarctic fur seal (Arctocephalus gazella) pups. Comp Biochem Physiol A 129, 829-841.

56. Cherel Y \& Le Maho Y (1985) Five months of fasting in king penguin chicks: body mass loss and fuel metabolism. Am J Physiol Regul Integr Comp Physiol 18, R387-R392.

57. Morris JG (2002) Idiosyncratic nutrient requirements of cats appear to be diet-induced evolutionary adaptations. Nutr Res Rev 15, 153-168.

58. Hendriks WH, Moughan PJ \& Tarttelin MF (1997) Urinary excretion of endogenous nitrogen metabolites in adult domestic cats using a protein-free diet and the regression technique. J Nutr 127, 623-629.

59. Biknevicius AR \& Van Valkenburg B (1996) Design for killing: craniodental adaptations of predators. In Carnivore Behavior, Ecology, and Evolution, pp. 393-428 [JL Gittleman, editor]. Ithaca, NY: Cornell University Press.

60. Mustonen AM, Puukka M, Pyykonen T, et al. (2005) Adaptations to fasting in the American mink (Mustela vison): nitrogen metabolism. J Comp Physiol B 175, 357-363.

61. Mayntz D, Nielsen VH, Sørensen A, et al. (2009) Balancing of protein and lipid intake by a mammalian carnivore, the mink, Mustela vison. Anim Behav 77, 349-355.

62. Schweigert FJ, Ryder OA, Rambeck WA, et al. (1990) The majority of vitamin A is transported as retinyl esters in the blood of most carnivores. Comp Biochem Physiol A Comp Physiol 95, 573-578.

63. Kienzle E (1993) Carbohydrate metabolism of the cat. 1. Activity of amylase in the gastrointestinal tract of the cat. J Anim Physiol Anim Nutr 69, 92-101.

64. Washizu T, Tanaka A, Sako T, et al. (1999) Comparison of the activities of enzymes related to glycolysis and gluconeogenesis in the liver of dogs and cats. Res Vet Sci 67, 205-206.

65. Coppinger RP and Coppinger L (editors) (2001) Dogs: $A$ Startling New Understanding of Canine Origin, Behavior and Evolution. New York, NY: Scribner.

66. Debraekeleer J (2000) Appendix L: nutrient profiles of commercial dog and cat foods. In Small Animal Clinical Nutrition, 4th ed., pp. 1073-1083 [MS Hand, CD Thatcher, RL Remillard and P Roudebush, editors]. Topeka, KS: Mark Morris Institute.

67. Murray SM, Flickinger AE, Patil AR, et al. (2001) In vitro fermentation characteristics of native and processed cereal grains and potato starch using ileal chyme from dogs. J Anim Sci 79, 435-444.

68. McCoullough DR \& Ullrey DE (1983) Proximate mineral and gross energy composition of white-tailed deer. $J$ Wildl Manage 47, 430-441.

69. Rule DC, Broughton KS, Shellito SM, et al. (2002) Comparison of muscle fatty acid profiles and cholesterol concentrations of bison, beef cattle, elk, and chicken. J Anim Sci 80, 1202-1211.

70. Cordain L, Watkins BA, Florant GL, et al. (2002) Fatty acid analysis of wild ruminant tissues: evolutionary implications for reducing diet-related chronic disease. Eur I Clin Nutr 56, 181-191.

71. Käkelä R \& Hyvärinen H (1996) Site-specific fatty acid composition in adipose tissues of several northern aquatic and terrestrial mammals. Comp Biochem Physiol B 115, 501-514.

72. Simopoulos AP (2002) The importance of the ratio of omega-6/omega-3 essential fatty acids. Biomed Pharmacother 56, 365-379.

73. Ahlstrøm $\varnothing$, Krogdahl A, Vhile SG, et al. (2004) Fatty acid composition in commercial dog foods. J Nutr 134, S2145-S2147.

74. Bauer JE (2006) Facilitative and functional fats in diets of cats and dogs. J Am Vet Med Assoc 229, 680-684.

75. Bauer JE (2007) Responses of dogs to dietary omega-3 fatty acids. J Am Vet Med Assoc 231, 1657-1661.

76. Bosch G, Beerda B, Hendriks WH, et al. (2007) Impact of nutrition on canine behaviour: current status and possible mechanisms. Nutr Res Rev 20, 180-194.

77. Depauw S, Bosch G, Hesta M, et al. (2012) Fermentation of animal components in strict carnivores: a comparative study with cheetah fecal inoculum. J Anim Sci 90, $2540-2548$

78. Sekirov I, Russell SL, Antunes LC, et al. (2010) Gut microbiota in health and disease. Physiol Rev 90, 859-904.

79. Konner M \& Boyd Eaton S (2010) Paleolithic nutrition: twenty-five years later. Nutr Clin Pract 25, 594-602.

80. Eaton SB, Konner M \& Shostak M (1988) Stone agers in the fast lane: chronic degenerative diseases in evolutionary perspective. Am J Med 84, 739-749.

81. Ansorge H, Kluth G \& Hahne S (2006) Feeding ecology of wolves Canis lupus returning to Germany. Acta Theriol 51, 99-106.

82. Ballard WB, Whitman JS \& Gardner CL (1987) Ecology of an exploited wolf population in South-Central Alaska. Wildl Monogr 98, 3-54.

83. Barja I (2009) Prey and prey-age preference by the Iberian wolf Canis lupus signatus in a multiple-prey ecosystem. Wildl Biol 15, 147-154.

84. Capitani C, Bertelli I, Varuzza P, et al. (2004) A comparative analysis of wolf (Canis lupus) diet in three different Italian ecosystems. Mamm Biol 69, 1-10.

85. Ciucci P, Boitani L, Pelliccioni ER, et al. (1996) A comparison of scat-analysis methods to assess the diet of the wolf Canis lupus. Wildl Biol 2, 37-48.

86. Ciucci P, Tosoni E \& Boitani L (2004) Assessment of the point-frame method to quantify wolf Canis lupus diet by scat analysis. Wildl Biol 10, 149-153.

87. Chavez AS \& Gese EM (2005) Food habits of wolves in relation to livestock depredations in northwestern Minnesota. Am Midl Nat 154, 253-263.

88. Cuesta L, Barcena F, Palacios F, et al. (1991) The trophic ecology of the Iberian wolf (Canis lupus signatus Cabrera, 1907). A new analysis of stomach's data. Mammalia 55, 239-254.

89. Forbes GJ \& Theberge JB (1996) Response by wolves to prey variation in central Ontario. Can J Zool 74, 1511-1520.

90. Fuller TK \& Keith LB (1980) Wolf population dynamics and prey relationships in northeastern Alberta. $J$ Wildl Manage 44, 583-602.

91. Jedrzejewski W, Jedrzejewska B, Okarma H, et al. (1992) Wolf predation and snow cover as mortality factors in the ungulate community of the Bialowieża National Park Poland. Oecologia 90, 27-36.

92. Jedrzejewski W, Schmidt K, Theuerkauf J, et al. (2002) Kill rates and predation by wolves on ungulate populations 
in Białowieża primeval forest (Poland). Ecology $\mathbf{8 3}$, $1341-1356$

93. Jethva BD \& Jhala YV (2004) Foraging ecology, economics and conservation of Indian wolves in the Bhal region of Gujarat, Western India. Biol Conserv 116, 351-357.

94. Kojola I, Huitu O, Toppinen K, et al. (2004) Predation on European wild forest reindeer (Rangifer tarandus) by wolves (Canis lupus) in Finland. J Zool 263, 229-235.

95. Lanszki J, Márkus M, Újváry D, et al. (2012) Diet of wolves Canis lupus returning to Hungary. Acta Theriol 57, 189-193.

96. Liu B \& Jiang Z (2003) Diet composition of wolves Canis lupus in the northeastern Qinghai-Tibet Plateau, China. Acta Theriol 48, 255-263.

97. Mattioli L, Apollonio M, Mazzarone V, et al. (1995) Wolf food habits and wild ungulate availability in the Foreste Casentinesi National Park, Italy. Acta Theriol 40, 387-402.

98. Mattioli L, Capitani C, Avanzinelli E, et al. (2004) Predation by wolves (Canis lupus) on roe deer (Capreolus capreolus) in north-eastern Apennine, Italy. J Zool 264, 249-258.

99. Messier F \& Crête M (1985) Moose-wolf dynamics and the regulation of moose populations. Oecologia 65, 503-512.

100. Milanesi P, Meriggi A \& Merli E (2012) Selection of wild ungulates by wolves Canis lupus (L. 1758) in an area of the Northern Apennines (North Italy). Ethol Ecol Evol 24 $81-96$.

101. Nowak S, Myslajek RW, Klosinska A, et al. (2011) Diet and prey selection of wolves (Canis lupus) recolonising Western and Central Poland. Mamm Biol 76, 709-715.
102. Olsson O, Wirtberg J, Andersson M, et al. (1997) Wolf Canis lupus predation on moose Alces alces and roe deer Capreolus capreolus in south-central Scandinavia. Wildl Biol 3, 13-23.

103. Peterson RO, Woolington JD \& Bailey TN (1984) Wolves of the Kenai Peninsula, Alaska. Wildl Monogr 88, 3-52.

104. Peterson RO \& Page RE (1988) The rise and fall of Isle Royal wolves, 1975-1986. J Mammal 69, 89-99.

105. Pezzo F, Parigi L \& Fico R (2003) Food habits of wolves in central Italy based on stomach and intestine analyses. Acta Theriol 48, 265-270.

106. Reed JE, Ballard WB, Gipson PS, et al. (2006) Diets of freeranging Mexican gray wolves in Arizona and New Mexico. Wildl Soc Bull 34, 1127-1133.

107. Reig S \& Jedrzejewski W (1988) Winter and early spring food for some carnivores in the Bialowieza National Park, Eastern Poland. Acta Theriol 33, 57-65.

108. Sidorovich VE, Tikhomirova LL \& Jedrzejewska B (2003) Wolf Canis lupus numbers, diet and damage to livestock in relation to hunting and ungulate abundance in northeastern Belarus during 1990-2000. Wildl Biol 9, 103-111.

109. Śmietana W \& Klimek A (1993) Diet of wolves in the Bieszczady Mountains, Poland. Acta Theriol 38, 245-251.

110. Thurber JM \& Peterson RO (1993) Effects of population density and pack size on the foraging ecology of gray wolves. J Mammal 74, 879-889.

111. Vos J (2000) Food habits and livestock depredation of two Iberian wolf packs (Canis lupus signatus) in the north of Portugal. J Zool 251, 457-462. 